\title{
Seasonal variation in metazoan parasites of Trichiurus lepturus (Perciformes: Trichiuridae) of Rio de Janeiro, Brazil
}

\author{
Carvalho, AR. ${ }^{a, b}$ and Luque, JL. ${ }^{c *}$ \\ aDepartamento de Educação e Ciências, \\ Instituto Federal de Educação, Ciência e Tecnologia do Sudeste de Minas Gerais, Campus Juiz de Fora, MG, Brazil \\ ${ }^{b}$ Laboratório de Taxonomia e Ecologia de Helmintos, Universidade Federal de Juiz de Fora - UFJF, MG, Brazil \\ 'Departamento de Parasitologia Animal, Universidade Federal Rural do Rio de Janeiro - UFRRJ, \\ CP 74508, CEP 23851-970, Seropédica, RJ, Brazil \\ *e-mail: jlluque@ufrrj.br
}

Received October 5, 2010 - Accepted December 6, 2010 - Distributed 31 August, 2011

(With 1 figure)

\begin{abstract}
This work aimed to study the temporal variation of metazoan parasites of Trichiurus lepturus from the coastal zone of Rio de Janeiro, Brazil. Between July 2006 and June 2007, there were four seasonal quarterly samples of 30 specimens of T. lepturus. In addition to a group composed of anisakid larvae, we collected a total of 14 species of metazoan parasites: five digenean; five monogenean, two cestode larvae, one acanthocephalan larvae; and one copepod. With the exception of Lecithochirium microstomum and Lecithochirium sp., all species showed peaks of prevalence and abundance especially those fishes collected in summer, which may indicate a seasonal variation of these parasites in T. lepturus from the coast of Rio de Janeiro.
\end{abstract}

Keywords: seasonality, parasite ecology, upwelling, cutlassfish.

\section{Variação sazonal dos metazoários parasitos de Trichiurus lepturus (Perciformes: Trichiuridae) do Rio de Janeiro, Brasil}

\begin{abstract}
Resumo
O presente trabalho teve como objetivo o estudo da variação temporal dos metazoários parasitos de Trichiurus lepturus do litoral do estado do Rio de Janeiro, Brasil. Entre julho de 2006 e junho de 2007, foram realizadas quatro coletas trimestrais de 30 espécimes de T. lepturus, coincidentes com as estações do ano. Além do grupo formado pelas larvas de anisaquídeos, foi coletado um total de 14 espécies de metazoários parasitos: cinco digenéticos; cinco monogenéticos; dois cestoides em estágio larval; um acantocéfalo e um copépode. Com exceção de L. microstomum e Lecithochirium sp., todas as espécies apresentaram picos de prevalência e abundância principalmente naqueles peixes coletados no verão, o que pode indicar uma variação sazonal dessas espécies de parasitos em $T$. lepturus do litoral do estado do Rio de Janeiro.
\end{abstract}

Palavras-chave: sazonalidade, ecologia de parasitos, ressurgência, peixe-espada.

\section{Introduction}

Communities of parasites of marine fish are often unstructured and unpredictable. The main reasons for this community profile are vagility, behaviour, physiology and feeding habits of the hosts as well as phylogenetic specificity and possible interactions between parasites (Luque et al., 2004; Luque and Poulin, 2008).

A large number of studies have focused on the structure of communities of parasites of marine fish. However, many do not address spatial-temporal variations or the determination of local processes and those of short duration that may affect the spatial-temporal dynamics of parasite populations and communities (Poulin and Valtonen,

2002). Processes such as variations in temperature and other abiotic factors, the abundance of intermediate hosts, changes in abundance, reproductive behaviour and diet of definitive hosts and factors related to host immunity have been suggested to influence the seasonal variation in communities of parasites of marine fish in tropical and sub-tropical regions (Chubb, 1979; Klimpel et al., 2003; Zander, 2003; 2004; Felis and Esch, 2004; Šimková, 2005). Moreover, studies have shown little quantitative variation in populations and communities of parasites of marine fish, suggesting that habitat use, foraging behaviour and the ontogeny of the hosts, along with variations in biotic 
and abiotic factors, are determinant factors in the parasite system, which is characterised by low colonisation rates and high residence time (Díaz and George-Nascimento, 2002; Timi and Poulin, 2003; González and Poulin, 2005).

The cutlassfish, Trichiurus lepturus Linnaeus, 1758, is a widely distributed species between latitudes $60^{\circ} \mathrm{N}$ and $45^{\circ} \mathrm{S}$. In the Atlantic Ocean, this species is distributed from Cape Cod, Massachusetts, USA $\left(40^{\circ} \mathrm{N}\right)$ to $\operatorname{Argentina}\left(37^{\circ} \mathrm{S}\right)$ from the coastline to depths of $350 \mathrm{~m}$ (Martins and Haimovici, 2000; FAO, 2005). Trichiurus lepturus is a demersal-pelagic species with a predominantly piscivorous diet, but high feeding plasticity (Chiou et al., 2006; Bittar et al., 2008). This species occupies an intermediate position in the marine food chain, feeding on species that are important fishery resources, and is predated by elasmobranchs and small cetaceans. The cutlassfish is among the six species with the greatest volume of fishery landings in the world (Martins and Haimovici, 2000; FAO, 2005; Martins et al., 2005; Chiou et al., 2006; Bittar et al., 2008).

Preliminary qualitative and quantitative studies on parasite fauna of T. lepturus in Brazil are summarised in Silva et al. (2000a,b). More recently, Carvalho and Luque $(2009,2010)$ recorded four species of monogeneans parasitic of T. lepturus from Rio de Janeiro. The aim of the present study was to investigate the seasonal variation in infrapopulations, infracommunities and metazoan parasites of T. lepturus in Guanabara Bay, Rio de Janeiro, RJ, Brazil.

\section{Material and Methods}

Between July 2006 and June 2007, four quarterly samples of T. lepturus were collected. Each collection included 30 specimens, a total of 120 fish. The first collection was performed in winter (July-September 2006), the second in spring (October-December 2006), the third in summer (January-March 2007) and fourth in the autumn (April-June 2007). All fish were purchased from the same professional fisherman and collected in Guanabara Bay (23 $3^{\circ}$ ' $52^{\prime}$ ' $\mathrm{S}$ and $43^{\circ} 11^{\prime} 56^{\prime}$ W), in the state of Rio de Janeiro, Brazil. Fish were identified according to Nakamura and Parin (1993).

All fish were weighed, measured and sexed according to Vazzoler (1996). To detect differences in nutritional status of the hosts between the sexes and the seasons, were calculated the factor $(\mathrm{K})$ of allometric condition (provided $\mathrm{x} 10^{-2}$ ) for all fish (Santos et al., 2004). The length-weight relationship was estimated according to Le Cren (1951). Differences between the length and weight of the hosts and the allometric condition factor for the total and for the seasonal samples were evaluated with ANOVA followed by an a posteriori Tukey test (Zar, 1999). The Student $t$-test was used to determine possible differences between the total length and weight between the males and females and to check the influence of sex of the hosts in the allometric condition factor $(\mathrm{K})$.

The analysis included only those species of parasites that had prevalence equal or greater than $10 \%$ in at least one of the collections. We calculated the following descriptors of parasite populations: prevalence, abundance and mean intensity. The comparison prevalence between total and seasonal samples was performed using the multiple comparison test for proportions (Zar, 1999). For those species of parasites present in two collections, the possible differences between prevalence were assessed using the chi-square $\left(\chi^{2}\right)$. Differences between the totals and average per collection in parasite abundance were evaluated with the ANOVA followed by an a posteriori Tukey test. The Student $t$-test was used to verify the possible influence of host sex on parasite abundance (Zar, 1999). The dominance frequency and mean relative dominance of each parasite species in each season was calculated according to Rohde et al. (1995).

The following descriptors of parasite communities were calculated: species richness, diversity (determined by the Brillouin diversity index $\mathrm{H}$ ) and evenness (based on Brillouin index J) (Zar, 1999; Magurran, 2007). The numerical dominance was calculated by the BergerParker index (d) (Magurran, 2007). Possible differences between parasite richness, dominance, parasite diversity and evenness in relation to total sample and to seasonal samples were evaluated with ANOVA followed by an a posteriori Tukey test (Zar, 1999). Data were log-transformed $\left[\log _{10}(\mathrm{x}+1)\right]($ Zar, 1999)

The ecological terminology used was recommended by Bush et al. (1997). The level of statistical significance was $\mathrm{p} \leq 0.05$.

\section{Results}

Table 1 lists the parasite species collected and identified. All specimens of T. lepturus collected were infected by at least one parasite species. A total of 46,830 parasites were collected, with an average of $390.3 \pm 444.3$ parasites/fish. The most prevalent and abundant were Lecithochirium microstomum, with 21,928 specimens (45.97\%), anisakid larvae, with 18,138 specimens (38.70\%), Scolex polymorphus, with 4800 specimens (10.25\%), and Metacaligus uruguayensis, with 1840 specimens (3.93\%).

Table 2 displays the values on total length, weight and allometric condition factor of the specimens of T. lepturus (total and per collection). Total length (ANOVA $\mathrm{F}_{3,196}=33.42 ; \mathrm{p}<0.001$ ), weight $\left(\mathrm{ANOVA} \mathrm{F}_{3,196}=40.85\right.$; $\mathrm{p}<0.001)$ and allometric condition factor $(\mathrm{K})$ (ANOVA $\left.\mathrm{F}_{3,196}=6.23 ; \mathrm{p}=0.001\right)$ of the fish exhibited significant differences between collections. Thirteen species of parasites and anisakid larvae were used for the comparative analysis between infrapopulations and infracommunities of metazoan parasites between seasonal samples (Table 3). The most prevalent species were L. microstomum in winter, summer and autumn, anisakids in spring, summer and autumn and $M$. uruguayensis in spring and summer. All three species had a prevalence rate of $100 \%$ in summer and were collected in all four seasons (Table 3 ). There was a statistically significant difference in parasite abundance between samples (ANOVA $\mathrm{F}_{3,116}=33.31$; $\mathrm{p}<0.001$ ), with greater abundance in summer and autumn (Table 4). With the exception of P. elongatus, O. travassosi and 
Table 1. Prevalence, intensity range, mean intensity, mean abundance, and site of infection of metazoan parasites of Trichiurus lepturus of Guanabara Bay, Rio de Janeiro, Brazil.

\begin{tabular}{|c|c|c|c|c|c|}
\hline Parasites & $\begin{array}{c}\text { Prevalence } \\
(\%)\end{array}$ & $\begin{array}{l}\text { Intensity } \\
\text { range }\end{array}$ & $\begin{array}{c}\text { Mean intensity } \\
\pm \text { SD }\end{array}$ & $\begin{array}{c}\text { Mean abundance } \\
\pm \text { SD } \\
\end{array}$ & $\begin{array}{c}\text { Site of } \\
\text { infection }\end{array}$ \\
\hline \multicolumn{6}{|l|}{ Digenea } \\
\hline Lecithochirium microstomum & 93.3 & $1-1451$ & $192.20 \pm 260.00$ & $179.40 \pm 255.70$ & $\begin{array}{l}\text { stomach and } \\
\text { intestine }\end{array}$ \\
\hline Lecithochirium sp. & 38.3 & $1-36$ & $8.10 \pm 8.60$ & $3.10 \pm 6.60$ & $\begin{array}{l}\text { stomach and } \\
\text { intestine }\end{array}$ \\
\hline Paramphistomiformes gen. sp. & 4.2 & $1-5$ & $2.40 \pm 1.70$ & $0.10 \pm 0.60$ & stomach \\
\hline Pseudopecoelus elongatus & 4.2 & $1-2$ & $1.61 \pm 0.50$ & $0.06 \pm 0.34$ & stomach \\
\hline Hemiurinae gen. sp. & 5.0 & $1-2$ & $1.33 \pm 0.50$ & $0.06 \pm 0.31$ & stomach \\
\hline \multicolumn{6}{|l|}{ Monogenea } \\
\hline Encotyllabe souzalimae & 7.5 & $1-4$ & $1.33 \pm 1.00$ & $0.10 \pm 0.44$ & $\begin{array}{c}\text { gills and } \\
\text { buccal cavity }\end{array}$ \\
\hline Microcotyle sp. & 3.3 & $1-3$ & $2.00 \pm 1.41$ & $0.03 \pm 0.29$ & Gills \\
\hline Neobenedenia melleni & 8.3 & $1-2$ & $1.26 \pm 0.40$ & $0.10 \pm 0.35$ & body surface \\
\hline Octoplectanocotyla travassosi & 12.5 & $1-4$ & $1.52 \pm 1.10$ & $0.19 \pm 0.63$ & Gills \\
\hline Pseudempleurosoma guanabarensis & 16.7 & $1-6$ & $1.64 \pm 1.30$ & $0.27 \pm 0.79$ & Esophagus \\
\hline \multicolumn{6}{|l|}{ Cestoda } \\
\hline $\begin{array}{l}\text { Callitetrarhynchus gracilis } \\
\text { (plerocercoid) }\end{array}$ & 12.5 & $1-12$ & $3.68 \pm 3.18$ & $0.46 \pm 1.60$ & Mesentery \\
\hline Scolex polymorphus (metacestode) & 65.0 & $1-832$ & $60.0 \pm 146.40$ & $39.0 \pm 121.20$ & $\begin{array}{l}\text { stomach and } \\
\text { intestine }\end{array}$ \\
\hline \multicolumn{6}{|l|}{ Acanthocephala } \\
\hline Polymorphus sp. (cystacanth) & 23.3 & $1-18$ & $3.93 \pm 3.82$ & $0.92 \pm 2.47$ & Mesentery \\
\hline \multicolumn{6}{|l|}{ Nematoda } \\
\hline Anisakidae (larvals) & 88.3 & $1-1881$ & $171.12 \pm 343.40$ & $151.20 \pm 327.30$ & Mesentery \\
\hline \multicolumn{6}{|l|}{ Copepoda } \\
\hline Metacaligus uruguayensis & 83.3 & $1-90$ & $18.40 \pm 17.90$ & $15.30 \pm 17.70$ & $\begin{array}{c}\text { gills and } \\
\text { buccal cavity }\end{array}$ \\
\hline
\end{tabular}

P. guanabarensis, all the other species exhibited temporal variations in abundance (Table 4).

The mean richness of parasite species in the infracommunities was $4.6 \pm 1.7$, with significant differences detected between total parasite richness and richness per collection $\left(\right.$ ANOVA F $F_{3,116}=17.99 ; \mathrm{p}<0.001$ ) (Table 5). The highest parasite richness values occurred in the summer and fall samples, represented by six species of parasites (Figure 1) (Table 5). Quantitative dominance in the infracommunities was high $(d=0.76 \pm 0.18)$ and relatively constant between samples $\left(\mathrm{ANOVA} \mathrm{F}_{3,16}=2.10\right.$; $\mathrm{p}=0.10$ ), indicating a stable community dominated by few species (L. microstomum, anisakid nematodes and M. uruguayensis), as confirmed by the frequency of dominance and mean relative dominance displayed by these species (Tables 5 and 6). However, it should be stressed that the mean total dominance was higher in the autumn and winter samples, reflecting the dominance of the trematode L. microstomum.
Mean parasite species diversity was $\mathrm{H}=0.26 \pm 0.14$, with variations regarding the total diversity and per collection (ANOVA $\mathrm{F}_{3,16}=5.56 ; \mathrm{p}=0.001$ ), reflecting the differences found in species richness and abundance (Table 5). Parasite species evenness was $\mathrm{J}=0.43 \pm 0.22$, with significant differences in the comparison of the total and seasonal samples (ANOVA $F_{3,116}=4.09 ; \mathrm{p}=0.008$ ); the highest values occurred in spring and the lowest in the autumn sample (Table 6).

There is no influence of host sex on parasite abundance, species richness, dominance, diversity and evenness of parasite infracommunities.

\section{Discussion}

The present study detected patterns among metazoan parasites of T. lepturus: occurrence of four species with the highest values of prevalence, intensity and abundance. Moreover, there were significant differences in the prevalence and abundance of species collected in two or more seasons. 
Carvalho, AR. and Luque, JL.

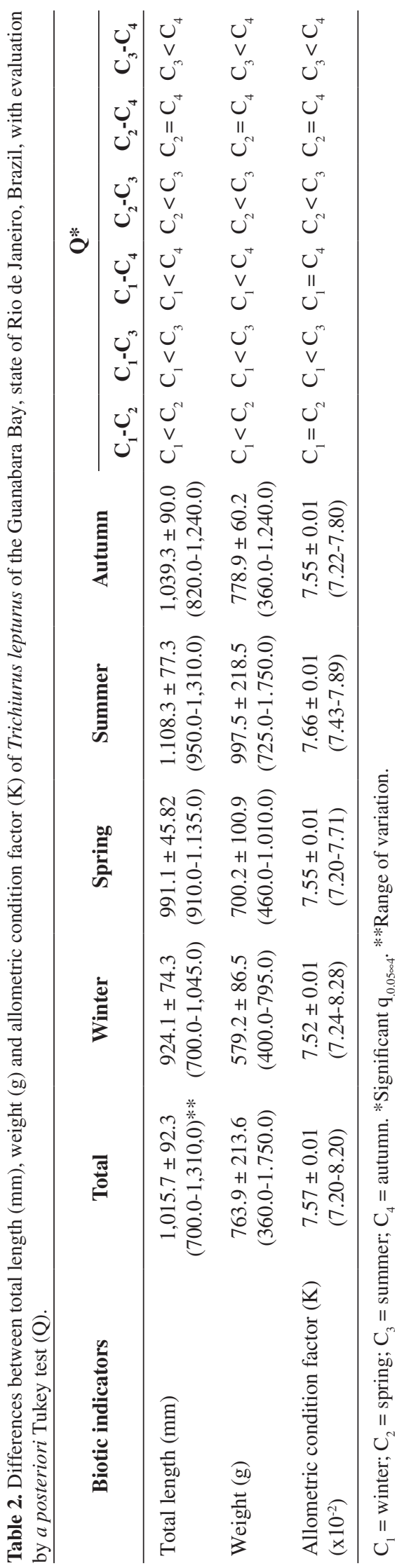


Table 3. Seasonal differences of the prevalence (\%) of species of metazoan parasites of Trichiurus lepturus in Guanabara Bay, Rio de Janeiro, Brazil.

\begin{tabular}{|c|c|c|c|c|c|c|}
\hline Parasites & Total & Winter & Spring & Summer & Autumn & $\mathbf{Q}^{*}$ \\
\hline \multicolumn{7}{|l|}{ Digenea } \\
\hline Lecithochirium microstomum & 93.3 & 96.7 & 76.7 & 100.0 & 100.0 & $14.45^{*}$ \\
\hline Lecithochirium sp. & 38.3 & 53.3 & 20.0 & 30.0 & 50.0 & $9.75^{*}$ \\
\hline Paramphistomiformes gen. sp. & 4.2 & 16.7 & 0 & 0 & 0 & --- \\
\hline Pseudopecoelus elongatus & 4.2 & 10.0 & 0 & 0 & 6.7 & 0.22 \\
\hline Hemiurinae gen. sp. & 5.0 & 13.3 & 0 & 0 & 6.7 & 0.47 \\
\hline \multicolumn{7}{|l|}{ Monogenea } \\
\hline Encotyllabe souzalimae & 7.5 & 0 & 3.3 & 26.7 & 0 & $6.41 *$ \\
\hline Microcotyle sp. & 3.3 & 0 & 0 & 3.3 & 3.3 & --- \\
\hline Neobenedenia melleni & 8.3 & 0 & 23.3 & 6.7 & 3.3 & $7.02 *$ \\
\hline Octoplectanocotyla travassosi & 12.5 & 0 & 3.3 & 26.7 & 20.0 & $6.15^{*}$ \\
\hline Pseudempleurosoma guanabarensis & 16.7 & 10.0 & 6.7 & 26.7 & 23.3 & 6.15 \\
\hline \multicolumn{7}{|l|}{ Cestoda } \\
\hline Callitetrarhynchus gracilis (plerocercoid) & 12.5 & 0 & 6.7 & 43.3 & 0 & $10.75 *$ \\
\hline Scolex polymorphus (metacestode) & 65.0 & 66.7 & 33.3 & 90.0 & 70.0 & $14.57 *$ \\
\hline \multicolumn{7}{|l|}{ Acanthocephala } \\
\hline Polymorphus sp. (cystacanth) & 23.3 & 0 & 0 & 73.3 & 20.0 & $17.14^{*}$ \\
\hline \multicolumn{7}{|l|}{ Nematoda } \\
\hline Anisakidae (larvals) & 88.3 & 73.3 & 90.0 & 100.0 & 90.0 & $10.41 *$ \\
\hline \multicolumn{7}{|l|}{ Copepoda } \\
\hline Metacaligus uruguayensis & 83.3 & 40.0 & 100.0 & 100.0 & 93.3 & $53.91 *$ \\
\hline Total prevalence & 100.0 & 100.0 & 100.0 & 100.0 & 100.0 & --- \\
\hline
\end{tabular}

$\mathrm{Q}=$ values of a posteriori Tukey test. *Significant $\mathrm{p} \leq 0.05$.

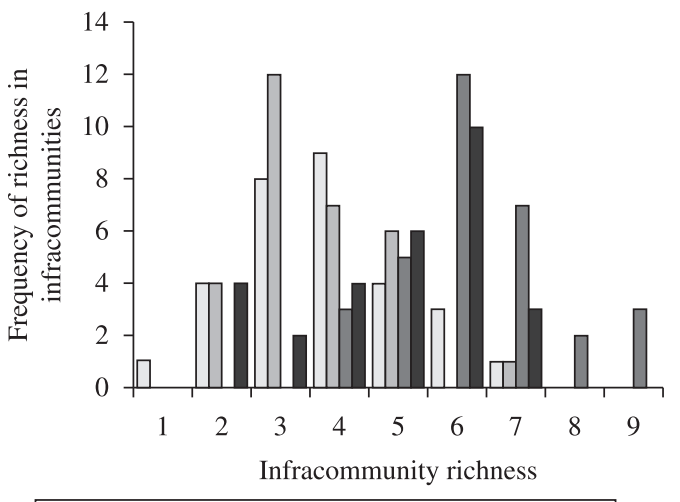

$\square$ Winter $\square$ Spring $\square$ Summer $\square$ Autumn

Figure 1. Seasonal variation in the frequency of the species richness of metazoan parasite infracommunities of Trichiurus lepturus in Guanabara Bay, Rio de Janeiro, Brazil.

The peaks in parasite prevalence and abundance were mainly in the summer sample. On the infracommunity level, trematodes, copepods and anisakid were dominant in all seasons, with the highest values of richness and diversity in the parasite communities found in the summer sample.

Allometric condition factor $(\mathrm{K})$ values were higher in summer, indicating that the fish had the greatest accumulation of body fat in this season (Santos and Fontoura, 2000). This is in agreement with the findings described by Bittar et al. (2008), who report higher $\mathrm{K}$ values in T. lepturus in the first year half and a peak in reproductive activity in this species in summer and late autumn/winter on the coast of the state of Rio de Janeiro (Brazil). This was also confirmed by the present study, with the lowest $\mathrm{K}$ values occurring in winter.

The feeding plasticity of T. lepturus and its intermediate position in the marine food chain indicate its importance as an intermediate or paratenic host for helminth parasites. In the present study, larval stages of cestodes, nematodes and acanthocephalans were found using T. lepturus as a paratenic host to reach the definitive hosts (elasmobranches, piscivorous birds and aquatic mammals) (Knoff et al., 2002; São Clemente et al., 2004; Tavares and Luque, 2006). The intermediate hosts used by these three groups of parasites are mainly represented by crustaceans, mollusks and fish, which are the predominant items in the diet of T. lepturus (Martins et al., 2005; Bittar et al., 2008). Thus, temporal variations in the availability of food items may have repercussions on the parasite fauna of T. lepturus, whereas the abundance and prevalence of parasites with complex life cycles depends directly on the free-living fauna (Campbell et al., 1980; Campbell, 1983).

The highest $\mathrm{K}$ values occurred in specimens collected in summer, coinciding with the period of upwelling, which indicates that the host population undergoes greater 


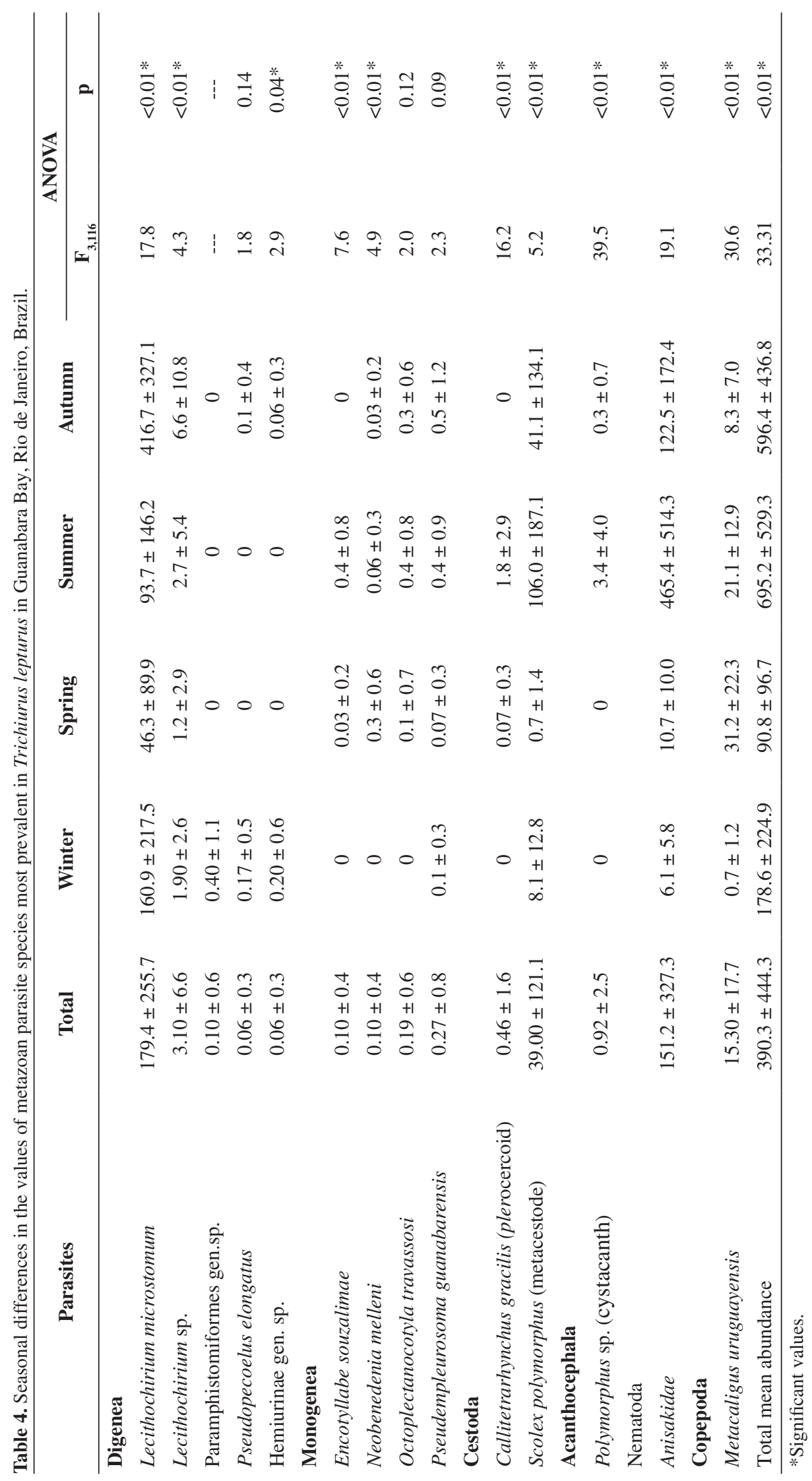









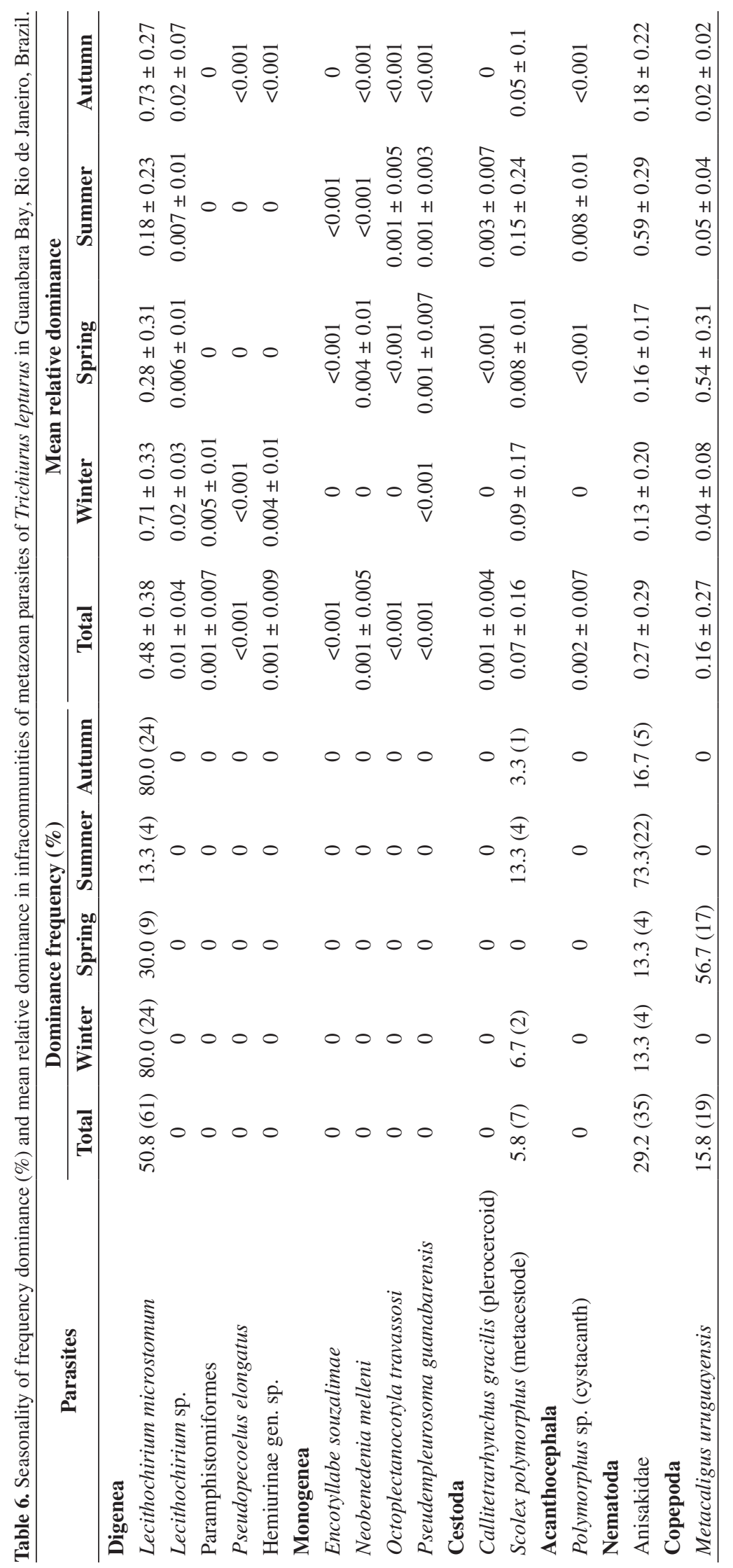


foraging activity in this season in order to store energy for the reproductive period in late summer and early autumn (Santos and Fontoura, 2000). According to Martins and Haimovici (1997), the reproduction of T. lepturus may be associated with local processes of productivity, since the upwelling areas that occur near the coast in summer (Garcia, 1997) coincide with the peak breeding of the species (Martins and Haimovici, 1997). This synchronicity between increased nutrient availability and the reproductive period is a strategy used by marine teleosts to ensure that the larvae have access to a greater concentration of food, thereby preventing their spreading out over a wider area and benefitting their survival (Bakun and Parrish, 1990).

The greater foraging activity by T. lepturus in summer was reflected in the quantitative and qualitative characteristics of populations of metazoan endoparasites. With the exception of digenean species, all other endoparasite species reached the greatest prevalence and abundance of parasitism in summer, which could indicate that an increase in aquatic productivity over a number of years may encourage seasonal cycles in some parasites and potential intermediate hosts, strengthening the evidence of a relationship between the cycles of the parasites and the availability of their hosts (Gil de Pertierra and Ostrowski de Nuñez, 1995; Moravec et al., 2002; Jiménez-Garcia and Vidal-Martinez, 2005).

Among the trematodes, peak prevalence and abundance occurred in autumn and winter, following the end of the peak breeding period of the fish. A number of authors have reported an association between reproduction and an increase in the prevalence and abundance of species of parasites and have attributed this fact to the physiological stress of the host during the breeding period, as a higher investment in reproduction may decrease the energy allocated to the immune system and thereby facilitate parasite infections (Sheldon and Verhulst, 1996; White et al., 1996; Šimková et al., 2005; Lizama et al., 2006). In the present study, the results found for digeneans suggest that host breeding may have influenced the population dynamics, as some species of parasites may develop the strategy of synchronizing their lifecycle with host reproduction (Šimková et al., 2005). Thus, for the metazoan endoparasites of T. lepturus, similarities were observed in the characteristics of the populations. For the larval stages, the consequences of environmental changes and upwelling as well as the behavioural and physiological changes in the hosts (increase in foraging and breeding) led to immediate changes. For the adult parasites, environmental changes and biological changes in the host had remarkable consequences after the peak of the reproductive process.

A number of studies have tested the epidemiological model (Dobson and Roberts, 1994; Roberts et al., 2002) to make predictions concerning the relationship between population density of the host and parasite populations and communities. The schooling behaviour and body size of the host are important to the dynamics of populations of ectoparasites, as a greater density of fish forming schools and larger area for infestation facilitate the spread of the parasite in the population (Ranta, 1992; Sasal and Morand, 1998; Raibaut et al., 1998; Poulin and Justine, 2008; Takemoto et al., 2009). In T. lepturus, individuals above $50 \mathrm{~cm}$ in length form schools that migrate, with movement and distribution influenced by oceanographic conditions (FAO, 2005). In the present study, both the conduct of schooling and the greater population aggregation that occurs as a result of reproduction may have led to the greater prevalence and abundance of copepods, represented by $M$. uruguayensis, throughout the collection period, with peaks during the reproductive period of the fish. Moreover, the greater population aggregation that occurs as a result of breeding may have determined the prevalence and abundance of monogeneans, as N. melleni, $E$. souzalimae and $O$. travassosi were only recorded during the reproductive period of the host. The exception was P. guanabarensis, which was collected in four samples.

With some exceptions, host size did not affect the prevalence of parasites in T. lepturus. However, total parasite abundance was positively associated with host total length and weight, a pattern that was only found in autumn. The abundance of each parasite species was not correlated to the size or the weight of host. Basic ecological differences between external and internal parasites did not appear to influence this relationship consistently. Larger fish provide more internal and external space for the establishment of parasites and have high rates of infection because they feed on a larger number of infected prey and provide a large contact area for the establishment of parasites (Poulin, 2000; Muñoz et al., 2005). However, one must be careful to avoid generalisations regarding the influence of host size on qualitative and quantitative composition of parasite fauna, as the parasitism may not necessarily increase with the size of the fish through a process of accumulation and longer exposure time, but may be related to changes in food items in different age groups of the host population and the population dynamics of intermediate hosts (Saad-Fares and Combes, 1992; Tavares and Luque, 2004).

The specimens of T. lepturus had similar length and weight in the spring and autumn, but greater abundances in parasite species occurred in autumn. This may indicate that not only length and weight are determinants in the population parameters of parasites, but temporal changes in diet and the biology of the hosts recorded during upwelling and reproduction may influence the degree of infection/ infestation of the hosts, which may constitute a clear indication of the temporal variation in infrapopulations of metazoan parasites of T. lepturus on the coast of Rio de Janeiro.

The analysis of feeding activity revealed that the feeding intensity of T. lepturus females was significantly lower in the reproductive period, whereas males had no variation in feeding intensity between the reproductive and non-reproductive period, with lower allometric condition factor values (Martins \& Haimovici, 1997). Differences in biological and ecological aspects between genders are expected to reflect in populations of parasites, especially 
with regard to T. lepturus, for which all endoparasites are obtained through the food chain. However, sex of the hosts did not influence the population (prevalence and abundance) and community (richness, diversity and dominance) parameters of the metazoan parasites, which indicates that there was no differential exposure to parasitism between sexes, as reflected in their degree of infection.

The aim of studying the population and community ecology of fish parasites is to determine their natural modifications, including both biotic and abiotic factors of the host-parasite system that affect its dynamics (Díaz and George-Nascimento, 2002). A large number of processes have been suggested to influence the seasonal variation in parasite communities in temperate regions, for example, temperature and other abiotic factors, abundance of intermediate hosts, changes in the abundance of hosts, food and reproductive behaviour and host immunity (Chubb, 1979; Šimková, 2005, among others). The infracommunities of parasites of T. lepturus had higher diversity values in the months related to the phenomenon of upwelling and the peak of the reproductive process of the fish, which may be related to the increase in marine productivity in the area studied as well as behavioural and physiological changes occurring in the host in this period.

Acknowledgements - Adriano R. de Carvalho was supported by a Doctoral fellowship from CNPq (Conselho Nacional de Pesquisa e Desenvolvimento Tecnológico, Brazil); and José L. Luque was partially supported by a Research fellowship from CNPq.

\section{References}

BAKUN, A. and PARRISH, RH., 1990. Comparative studies of coastal pelagic fish reproductive habitats: the Brazilian sardine (Sardinella aurita). Journal du Conseil International pour L'Exploration de la Mer, vol. 46, no. 3, p. 269-283.

BITTAR, VT., CASTELO, BFL. and DI BENEDITTO, APM., 2008. Hábito alimentar do peixe-espada adulto, Trichiurus lepturus, na costa norte do Rio de Janeiro, sudeste do Brasil. Biotemas, vol. 21 , no. 2 , p. $83-90$.

BUSH, AO., LAFFERTY, KD., LOTZ, JM. and SHOSTAK, AW., 1997. Parasitology meets ecology on its own terms: Margolis et al. revisited. Journal of Parasitology, vol. 83, no. 4, p. $575-583$.

CAMPBELL, R., 1983. Parasitism in the deep sea. In ROWE, GT. (Ed.). The Sea. New Jersey: Wiley and Sons Inc. p. 473-552.

CAMPBELL, RA., HAEDRICH, RL. and MUNROE, TA., 1980. Parasitism and ecological relationships among deep-sea benthic fishes. Marine Biology, vol. 57, no. 2, p. 301-313.

CARVALHO, AR. and LUQUE, JL., 2009. Ocorrência de Neobenedenia melleni (Monogenea, Capsalidae) em Trichiurus lepturus (Perciformes, Trichiuridae), naturalmente infestados, no litoral do Rio de Janeiro, Brasil. Revista Brasileira de Parasitologia Veterinária, vol. 18, supl. 1, p. 76-76.

-, 2010. Three new species of monogeneans parasitic on Atlantic cutlassfish Trichiurus lepturus (Perciformes: Trichiuridae) from Southeastern Brazil. Acta Scientiarum, in press.
CHIOU, WD., CHEN, CY., WANG, CM. and CHEN, CT., 2006. Food and feeding habits of ribbonfish Trichiurus lepturus in coastal waters of south-western Taiwan. Fisheries Science, vol. 72 , no. 3 , p. $373-381$

CHUBB, JC., 1979. Occurence of helminths in freshwater fishes. Part II. Trematoda. Advances in Parasitology, v. 17, p. 141-313. http://dx.doi.org/10.1016/S0065-308X(08)60551-5

DÍAZ, F. and GEORGE-NASCIMENTO, M. 2002. Estabilidad temporal de las infracomunidades de parasitos em la borrachilla Scartichthys viridis (Valenciennes, 1836) (Pisces: Blenniidae) em la costa central de Chile. Revista Chilena de História Natural, vol. 75 , no. 4, p. 641-649.

DOBSON, AP. and ROBERTS, M., 1994. The population dynamics of parasitic helminth communities. Parasitology, vol. 109, supl., p. S97-S108.

Food and Agricultural Organization - FAO, 2005. Available from: <www.fao.org/figis/servlet/FiRefServlet?ds=species\&f id $=2468>$. Access in: 12 maio 2010 .

FELIS, KJ. and ESCH, GW., 2004. Community structure and seasonal dynamics of the helminth parasites in Lepomis cyanellus e L. macrochirus from Charles pond, North Carolina: host size and species as determinants of community structure. Journal of Parasitology, vol. 90, no. 1, p. 41-49.

GARCIA, CAE., 1997. Coastal and marine environment and their biota: Physical Oceanography. In SEELIGER, U., ODEBRECHT, C. and CASTELLO, JP. (Eds.). Subtropical convergence environments. The coast and sea in the southwestern Atlantic. Berlin: Springer. p. 129-136.

GIL DE PERTIERRA, AA. and OSTROWSKI DE NÚÑEZ, M., 1995. Ocurrencia estacional de Acanthostomum gnerii Szidat, 1954 (Acanthostomidae, Acanthostominae) y de dos especies de Derogenidae, Halipeginae, Parasitos del bagre sapo, Rhamdia sapo Valenciennes, 1840 (Pisces, Pimelodidae) em Argentina. Revista Brasileira de Biologia, vol. 55, no. 2, p. 305-314.

GONZÁLEZ, MT. and POULIN, R., 2005. Spatial and temporal predictability of parasite community structure of a benthic marine fish along its distributional range. International Journal for Parasitology, vol. 35, no. 7, p. 1369-1377.

JIMENEZ-GARCÍA, MI. and VIDAL-MARTÍNEZ, VM., 2005. Temporal variation in the infection dynamics and maturation cycle of Oligogonotylus manteri (Digenea) in the cichlid fish, Cichlasoma urophthalmus, from Yucatán, México. Journal of Parasitology, vol. 91, no. 5, p. 1008-1014.

KLIMPEL, S., SEEHAGEN, A. and PALM, HW., 2003. Metazoan parasites and feeding behaviour of four small-sized fish species from the central North Sea. Parasitology Research, vol. 91, no. 2, p. 290-297. http://dx.doi.org/10.1007/s00436-003-0957-8

KNOFF, M., SÃO CLEMENTE, SC., PINTO, RM. and GOMES, DC., 2002. Prevalência e intensidade de infecção de cestóides Trypanorhyncha em elasmobrânquios nos do Paraná e Santa Catarina, Brasil. Parasitologia Latinoamericana, vol. 57, no. 3-4, p. $149-157$

LE CREN, ED., 1951. The length-weight relationship and seasonal cycle in gonad weight and condition in the pearch (Perca fluviatilis). Journal of Animal Ecology, vol. 20, no. 2, p. 201-219.

LIZAMA, MAP., TAKEMOTO, RM. and PAVANELLI, GC., 2006. Influence of the seasonal and environmental patterns and host reproduction on the metazoan parasites of Prochilodus 
lineatus. Brazilian Archives of Biology and Technology, vol. 49, no. 4, p. 611-622.

LUQUE, JL. and POULIN, R., 2008. Linking ecology with parasite diversity in Neotropical fishes. Journal of Fish Biology, vol. 72 , no. 1, p. 189-204.

LUQUE, JL., MOUILLOT, D. and POULIN, R., 2004. Parasite biodiversity and its determinants in coastal marine teleost fishes of Brazil. Parasitology, vol. 128, no. 5, p. 671-682.

MAGURRAN, AE., 2007. Ecological Diversity and its Measurement. Princeton: Princeton University Press. 179 p.

MARTINS, AS. and HAIMOVICI, M., 1997. Distribution, abundance and biological interactions of the cutlassfish Trichiurus lepturus in the southern Brazil suptropical convergence ecosystem. Fisheries Research, vol. 30, no. 3, p. 217-227.

-, 2000. Reproduction of the cutlassfish Trichiurus lepturus in the southern Brazil subtropical convergence ecosystem. Scientia Marina, vol. 64, no. 1, p. 97-105.

MARTINS, AS., HAIMOVICI, M. and PALACIOS, R., 2005. Diet and feeding of the cutlassfish Trichiurus lepturus in the Subtropical Convergence Ecosystem of southern Brazil. Journal of the Marine Biological Association of United Kingdom, vol. 85, p. 1223-1229.

MORAVEC, F., MENDOZA-FRANCO, E., VIVAS-RODRÍGUEZ, C., VARGAS-VÁSQUEZ, J. and GONZÁLES-SOLÍS, D., 2002. Observations on seasonal changes in the occurrence and maturation of five helminth species in the pimelodid catfish, Rhamdia guatemalensis, in the cenote (=sinkhole) Ixin-há. Yucatán. Mexico. Acta Societas Zoologicae Bohemicae, vol. 66, no. 1, p. 121-140.

MUÑOZ, G. and CRIBB, TH., 2005. Infracommunity structure of parasite of Hemigymnus melapterus (Pisces: Labridae) from Lizard Island, Australia, the importance of habitat and parasite body size. Journal of Parasitology, vol. 91, no. 1, p. 38-44.

NAKAMURA, I. and PARIN, NV., 1993. Snake mackerels and cutlassfishes of the world (Families Gempylidae and Trichiurudae). FAO Fisheries Synopsis, vol. 15, no. 125, 136 p.

POULIN, R., 2000. Variation in the intraspecific relationship between fish length and intensity of parasitic infection: biological and statistical causes. Journal of Fish Biology, vol. 56, no. 2, p. 123-137. http://dx.doi.org/10.1111/j.1095-8649.2000.tb02090.x

POULIN, R. and VALTONEN, ET., 2002. The predictability of helminth community structure in space: a comparison of fish populations from adjacent lakes. International Journal for Parasitology, vol. 32, no. 10, p. 1235-1243. PMid:18373272. http://dx.doi.org/10.1016/S0020-7519(02)00109-1

POULIN, R. and JUSTINE, JL., 2008. Linking species abundance distributions and body size in monogenean communities. Parasitology Research, vol. 103, no. 2, p. 187-193. http://dx.doi.org/10.1007/ s00436-008-0953-0

RAIBAUT, A., COMBES, C. and BENOIT, F., 1998. Analysis of the parasitic copepod species richness among Mediterranean fish. Journal of Marine Systems, vol. 15, no. 3, p. 185-206. http:// dx.doi.org/10.1016/S0924-7963(97)00079-1

RANTA, E., 1992. Gregariousness versus solitude: another look at parasite faunal richness in Canadian freshwater fishes. Oecologia, vol. 89, no. 2, p. 150-152. http://dx.doi.org/10.1007/BF00319028

ROBERTS, MG., DOBSON, AP., ARNEBERG, P., DE LEO, GA., KRECEK, RC., MANFREDI, MT., LANFRANCHI, P. and ZAFFARONI, E., 2002. Parasite community ecology and biodiversity. In HUDSON, PJ., RIZZOLI, A., GRENFELL, BT., HEESTERBEEK, H. and DOBSON, A.P. (Eds.). The Ecology of Wildlife Diseases. Oxford: Oxford University Press. p. 63-82.

ROHDE, K., HAYWARD, C. and HEAP, M., 1995. Aspects of the ecology of metazoan ectoparasites of marine fishes. International Journal for Parasitology, vol. 25, no. 8, p. 945-970. PMid:1452993. http://dx.doi.org/10.1016/0020-7519(95)00015-T

SAAD-FARES, A. and COMBES, C., 1992. Abundance-host size relationships in a fish trematode community. Journal of Helminthology, vol. 66, no. 2, p. 187-192. http://dx.doi.org/10.1017/ S0022149X00014541

SANTOS, GO. and FONTOURA, NF., 2000. Dinâmica reprodutiva de Geophagus brasiliensis (Quoy e Gaimard, 1824) (Teleostei - Cichlidae), do açude Águas Belas, Viamão, Rio Grande do Sul. Pesquisa Agropecuária Gaucha, vol. 6, no. 1, p. 131-144.

SANTOS, AFGN., SANTOS, LN. and ARAUJO, FG., 2004. Water level influences on body condition of Geophagus brasiliensis (Perciformes, Cichlidae) in a Brazilian oligotrophic reservoir. Neotropical Ichthyology, vol. 2, no. 3, p. 151-156.

SÃO CLEMENTE, SC., KNOFF, M., PADOVANI, RES., LIMA, FC. and GOMES, DC., 2004. Cestóides Trypanorhyncha parasitos de congro-rosa, Genypterus brasiliensis Regan 1903 comercializados nos municípios de Niterói e Rio de Janeiro, Brasil. Revista Brasileira de Parasitologia Veterinária, vol. 13, no. 3, p. 97-102.

SASAL, P. and MORAND, S., 1998. Comparative analysis: a tool for studying monogenean ecology and evolution. International Journal for Parasitology, vol. 28, p. 1637-1644. http://dx.doi. org/10.1016/S0020-7519(98)00084-8

SHELDON, BC. and VERHULST, S., 1996. Ecological immunology: costly parasite defences and trade-offs in evolutionary ecology. Trends in Ecology and Evolution, vol. 11, p. 317-321. PMid: 15565460. http://dx.doi.org/10.1016/0169-5347(96)10039-2

SILVA, LGO., LUQUE, JL. and ALVES, DR., 2000a. Metazoan parasites of the Atlantic cutlassfish, Trichiurus lepturus (Osteichthyes: Trichiuridae) from the coastal zone of Rio de Janeiro State, Brazil. Parasitologia al Dia, v. 24, n. 2, p. 97-101.

SILVA, LGO., LUQUE, JL., ALVES, DR. and PARAGUASSÚ, AR., 2000b. Ecologia da comunidade parasitária do peixe-espada Trichiurus lepturus (Osteichthyes: Trichiuridae) do litoral do estado do Rio de Janeiro, Brasil. Revista Brasileira de Zoociências, v. 2, n. 2, p. 115-133.

ŠIMKOVÁ, A., JARKOVSKY, J., KOUBKOVÁ, B., BARUS, V. and PROKES, M., 2005. Associations between fish reproductive cycle and the dynamics of metazoan parasite infections. Parasitology Research, vol. 95, no. 1, p. 65-72.

TAKEMOTO, RM., PAVANELLI, GC., LIZAMA, MAP., LACERDA, ACF., YAMADA, FH., MOREIRA, LHA., CESCHINI, T.L. and BELLAY, S., 2009. Diversity of parasites of fish from the Upper Paraná River floodplain, Brazil. Brazilian Journal of Biology, vol. 69, no. 6, p. 691-705.

TAVARES, LER. and LUQUE, JL., 2004. Community ecology of metazoan parasites of the later juvenile common snook Centropomus undecimalis (Osteichthyes: Centropomidae) from the coastal zone of the State of Rio de Janeiro, Brazil. Brazilian Journal of Biology, vol. 64, no. 3A, p. 523-529.

TAVARES, LER. and LUQUE, JL., 2006. Sistemática, biologia e importância em saúde coletiva de larvas de Anisakidae (Nematoda: 
Ascaridoidea) parasitas de peixes ósseos marinhos do Estado do Rio de Janeiro, Brasil. In SILVA-SOUZA, AT. (Ed.). Sanidade de Organismos Aquáticos no Brasil. Maringá: Abrapoa. p. 297-328.

TIMI, JT. and POULIN, R., 2003. Parasite community structure within and across host populations of a marine pelagic fish: how repeatable is it? International Journal for Parasitology, vol. 33, no. 8, p. 1353-1362.

VAZZOLER, AEAM. Biologia da reprodução de peixes teleósteos: teoria e prática. Maringá: EDUEM, 1996.196p.

WHITE, KAJ., GRENFEL, BT., HENDRY, RJ., LEJEUNE, O. and MURRAY, JD., 1996. Effect of seasonal host reproduction on host-macroparasite dynamics. Mathematics to Biosciences, vol. 137, no. 1, p. 79-99.

ZANDER, CD., 2003 Four-year monitoring of parasite communities in gobiid fishes of the south-western Baltic. I. Guild and component community. Parasitology Research, vol. 90, no. 3, p. 502-511.

-, 2004 Four-year monitoring of parasite communities in gobiid fishes of the south-western Baltic. II. Infracommunity. Parasitology Research, vol. 93, no. 1, p. 17-29.

ZAR, JH., 1999. Biostatistical analysis. New Jersey: PrenticeHall, Inc. 663 p. 